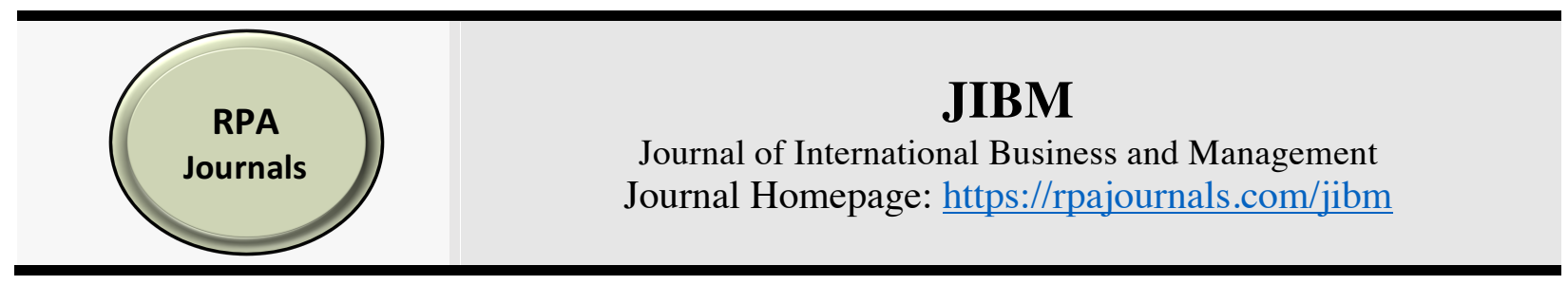

\title{
Performance Management in Saudi Arabia: The Effects of Employee Engagement, Physical Fitness and Healthy Lifestyle on Job Performance towards Absenteeism
}

\author{
Ahmed Abdulaziz Alashab \\ Khaliq Ahmad Mohamad ${ }^{*}$ \\ College of Business and Economics (CBE) ${ }^{12}$ \\ Qassim University, Buraydah, Saudi Arabia'.2
}

\begin{abstract}
This study has been conducted to identify the effect of employees' engagement, physical fitness including their style (behaviour) on job performance and absenteeism from work in Saudi Arabia. This is a significant study due to the fact that absenteeism from the work has a direct effect on productivity and organisations' performance. Absenteeism is a continuous pattern of absence from duty without a reasonable excuse and leads to poor performance. The study encompasses an investigation on the impact of the above three independent variables through empirical research and data analysis. This study is carried out by the survey method and is empirical in nature. The tool used in this study for analysis is the regression model developed by Sir Francis Galton. The results show a positive relationship between independent variables (employee engagement and healthy behaviour) and the dependent variables (job performance). However, there is not a strong relationship between the third independent variable (physical health) and job performance. The second dependent variable which is absenteeism and result shows no relationship with any independent variables (employee engagement, physical fitness and healthy behaviour).
\end{abstract}

Keywords: Management Performance, Employee Engagement, Physical Fitness, Healthy Behaviour

*Corresponding author: Khaliq Ahmad Mohamad; Email: k.israil@qu.edu.sa

DOI: https://doi.org/10.37227/jibm-2020-03-49/

\section{Introduction}

Over the years, organizations have sought ways to improve the management of human resources, with a particular focus on reducing absenteeism and increasing work performance. Absenteeism is defined as any failure of the employee to report for work as scheduled, regardless of cause, and the implied impact is expressed (Cascio, 2003). The term "as scheduled" is very important which includes vacations; holidays and other types of unplanned absence from work etc. It also eliminates the problem of whether absences are an excuse really or otherwise. A common example is medically verified illness when the employee is absent that means he or she was not available to perform his or her job as per 
schedule, in end results, absenteeism costs money. Tiwari (2014), said absenteeism is when employees absence from their job without prior permission. An unscheduled absence occurs when the employee is not attending his/her job during a normally scheduled working time. Absence is generally compensated if justification is within the guidelines specified in the organization's Attendance Policy. These compensatory absences may depend on the required actions of the employee. For example, prior permission to scheduled absences from work or notification of an unscheduled absence within time limits expected of the organisation and its management. In some organizations, employee has to submit medical report to prove his or her sickness in the time of his / her absence from duty. Many unscheduled absences can lead to the termination of the employment relationship. This is generally subject to the policies of the organization regarding leaves from the work. Performance standards are basics for employee behaviour at work. These rules are more about the way an employee works. Employees are assessed and classified in the performance of their duties compared to a number of criteria established by the employer as part of job requirements. The job description is the main part of the job performance. What an employee should do determines how the work should be done. In most cases quality and quantity are the two units of measures undertaken by respective employers.

Establishing criteria is the measure in which an employee's work depends directly on the extent to which it is carried out. Employers demand high productivity and quality at a workplace. If employees have a lot of work, it can also affect their performance. If an employee does not have enough work either, the business also suffers. Productivity is therefore become an issue and often hampered by excessive absences, poor attitudes, lack of teamwork and many mistakes at the workplace. Individual performance has high priority to both organizations and individuals. Performing tasks with high performance results is complacency, self-confidence, and mastery (Bandura, 1997; Kanfer et al., 2005). In addition, high performing individuals receive promotions, awards and recognitions. Job opportunities for employees who perform well are far better than career opportunities for employees of average or low performance at work place.

Since the study refers to the performance management and absenteeism of Saudi Arabian employees, it is necessary to understand the bureaucracy in the Kingdom and its evolution from historical perspective. Saudi Arabia is one of the members of the GCC group and occupies land area about four-fifths of the Arabian Peninsula. Saudi Arabia has 2.25 million square kilometres with more than 33 million inhabitants. Saudi Arabia has an oilbased economy that is under controls of the government's agencies, constitutes most important economic activities in the Kingdom. According to the 54th Annual Report of SAMA (Saudi Arabia Monetary Authority) in 2018, the total number of employees in Saudi Arabia was $11,445,057$, in which $27 \%$ is Saudi Arabia and $73 \%$ is non-Saudi workers who are mostly expatriates. The total number of Saudi employees are 3,063,397, in which $1,190,195(64.9 \%)$ are men and 1,073,202 (35.1\%) are women. These statistics relate to Saudi employees (men and women) in the public and private sectors. The rest are foreign workers among these $97 \%$ are men and rest are women.

These statistics refer to foreign personnel (men and women) from both government and private sectors. The present research focuses on the extent to which the absence of employees affects the organization in terms of cost control and performance of work, but there are several factors that play an important role which are employee engagement, healthy behaviours, and physical health conditions. According to a study that was conducted previously aimed to comprehend the effect of these variables on job performance and absenteeism. In results, employee engagement, healthy behaviour and physical health 
indicators were significantly associated with work performance and absenteeism. An employee engagement has a greater correlation with work performance compared to healthy behaviours or physical health indicators, while the physical health index was strongly associated with absence. The specific elements of the indicators were assessed on the basis of their association with self-classified work performance and absence (Merrill, Aldana, et al, 2013)

There is a need to study the impact of employees' performance due to its lasting impact on organisational productivity. There exists a problem of declining efficiency of workers due to poor health conditions and absenteeism from work. This study therefore examines the effect of employee engagement, healthy life style, and physical health on job performance due to absenteeism problem in Saudi Arabia. Therefore, the purposes of this study is to (a) identify the impact of employee engagement on job performance and absenteeism (b) identify the impact of healthy behaviour on job performance and absenteeism and (c) identify the impact of physical health on job performance and absenteeism. The main contribution of this study is the combination of employee engagement, health behaviour and condition of physical health indicators in a study of their relationship to job performance and absenteeism. Helpfully it gives the reader better understanding of the importance to improve worker's productivity where it takes a holistic approach encompassing employee health improvement and engagement strategies.

The present study is to know the impact on employees' performance due to its lasting impact on organisational productivity and problem of declining efficiency of workers due to poor health conditions and absenteeism from work. The purposes of this study is to (a) identify the impact of employee engagement on job performance and absenteeism (b) identify the impact of healthy behaviour on job performance and absenteeism and (c) identify the impact of physical health on job performance and absenteeism. The main contribution of this study is the combination of employee engagement, healthy behaviour and condition of physical health indicators and their relationship to job performance and absenteeism in Saudi Arabia. Hopefully the results give the readers better understanding and a need to improve worker's productivity where it takes a holistic approach encompassing employee health improvement and engagement strategies. The study plan encompasses a process of a questionnaire based survey and data analysis from the Qassim region of the Kingdom. This research is significant since the findings of the study aim to help the employees with knowledge consequently to help them, both the employees and the organization. To do so, it is necessary to look at each concept separately, and then to tie them together through common principles and ideas as depicted in the conceptual framework (Fig.1). The elaboration of these variables is followed in the literature review given below.

\section{Literature Review}

There are many factors that affect job performance and reduce absenteeism among employees. Organizations focus on getting high performance and reducing absenteeism rate. Therefore, the study report based on below three factors had direct effect on job performance and absenteeism. These factors are: i) employee engagement, ii) health behaviour, and iii) physical health which many previous researches have examined as these have the high impact on organizations' performance. The following diagram presents the conceptual model of this research. 


\section{Job Performance \& Absenteeism}

In an increasingly competitive global economy, employers need a healthier and more committed workforce. To this end, employers implement various programs to improve employee health eventually to improve work performance. Job performance is one of the most important dependent variables that affect organizations and individuals alike. Showing high performance when performing assigned tasks leads to satisfaction, self-efficacy and mastery (Bandura, 1997; Kanfer et aL, 2005). Job performance is defined as the effective implementation of tasks or functions and a positive contribution to the socio-economic work environment. A distinction can be made between performance and effectiveness. This is a set of performance results that may be influenced to some extent by factors other than individual performance.

Absenteeism has long been a concern of organizations and one of the oldest research topics in organizational psychology (Johns, 2003). Hundreds of studies have examined this phenomenon and tried to understand not only the determinants but also the consequences of such inevitable and undesirable behaviour (Rhodes \& Steers, 1990). A study defines absenteeism as "lack of physical presence in behaviour when and where one is expected it" (Harrison \& Price, 2003, p. 204). However, absenteeism remains a main problem in many countries (Bacharach, Bamberger, \& Biron, 2010; De Paola, 2010) in the twenty first century, concludes the study.

\section{Employee Engagement}

Managers and organizational supervisors can improve job satisfaction by creating a work environment in which mutual respect, encouragement, confidence, openness, and missionary commitment are created by providing opportunities for development and giving employees the opportunity to do so (Schneider, 2006). In other words, leadership skills can help make employees more "engaged," while others see their work as healthy support. Because these would generally have more resources to manage work related stress. Health and employee engagement are key factors in their productivity. It is important to understand how these factors work together to increase employee productivity at a workplace. In addition, engaging with the employer and mutual consultation encourages job satisfaction, loyalty, and pride that contributes to an increased productivity and reduce absenteeism (Krueger \& Killham, 2005). A deeper understanding would better inform staff about possible interventions needed to increase workers' productivity and reduce absenteeism. The aim is to understand the common effects of employee engagement, healthy behaviour and physical health on work performance and absenteeism.

\section{Physical Health}

Physical health and employee's fitness plays an important role in managing absenteeism, a clear indication against dysfunctional physic. Physical health is directly related to work performance. There are several benefits of physical activity which are well documented. Very solid scientific evidence, based on a variety of well-designed studies, suggests that physically active employees have a higher level of health-related physical condition, less risky profiles to develop diseases and lower rates of chronic diseases than other less active employees (Physical Activity Guidelines Advisory Committee, 2008). Physically active adult men and women have lower disease rates that cause death, heart disease, stroke, type 2 diabetes, colon cancer, breast cancer, depression, high blood pressure and metabolic syndrome. The role of physical activity and cardiac fitness has also been considered in the context of labour productivity and medical expenditure. Although the relationship between 
physical activity and productivity indicators is unclear, recent findings indicate the positive effects of physical activity on job performance, employee participation in the fitness program in case of absenteeism and strong physical activity in minimizing sick leaves (Proper and van Mechelen 2008).

Table 1- Relevant Studies on Dependent and Independent Factors

\begin{tabular}{|c|c|c|c|c|c|}
\hline No & $\begin{array}{l}\text { Author Name, } \\
\text { Year, Title }\end{array}$ & $\begin{array}{l}\text { Dependent } \\
\text { Variable }\end{array}$ & $\begin{array}{l}\text { Independent } \\
\text { Variable }\end{array}$ & $\begin{array}{l}\text { Statistical } \\
\text { Methods }\end{array}$ & Main results \\
\hline 1 & $\begin{array}{l}\text { Ikhlas I } \\
\text { Altarawneh,(2016), } \\
\text { Strategic Human } \\
\text { Resources } \\
\text { Management } \\
\text { (SHRM) and its } \\
\text { Impact on } \\
\text { Performance: The } \\
\text { Case from Saudi }\end{array}$ & $\begin{array}{l}\text { organizational } \\
\text { performance }\end{array}$ & $\begin{array}{l}\text { Managing human } \\
\text { resources. } \\
\text { Positive impact of } \\
\text { (SHRM) } \\
\text { Different impact } \\
\text { of (SHRM) }\end{array}$ & $\begin{array}{l}\text { Cranoch's } \\
\text { Alpha } \\
\text { Coefficient. } \\
\text { Frequencies, } \\
\text { arithmetic } \\
\text { means, and } \\
\text { percentages } \\
\text { Self- } \\
\text { administrated } \\
\text { standardized } \\
\text { questionnaire }\end{array}$ & $\begin{array}{l}\text { (SHRM) positively } \\
\text { affect the } \\
\text { organizational } \\
\text { performance which can } \\
\text { be represented by } \\
\text { increasing profits, } \\
\text { increasing the sales } \\
\text { ratios, increasing job } \\
\text { satisfaction and } \\
\text { increasing the loyalty } \\
\text { of employees. }\end{array}$ \\
\hline 2 & $\begin{array}{l}\text { Bhattacharya, M., } \\
\text { Gibson, D. E., \& } \\
\text { Doty, D. H. (2005). } \\
\text { The Effects of } \\
\text { Flexibility in } \\
\text { Employee Skills, } \\
\text { Employee } \\
\text { Behaviours, and } \\
\text { Human Resource } \\
\text { Practices on Firm } \\
\text { Performance }\end{array}$ & $\begin{array}{l}\text { Firm financial } \\
\text { performance. } \\
\text { cost- } \\
\text { efficiency }\end{array}$ & $\begin{array}{l}\text { Employee skill } \\
\text { flexibility. } \\
\text { Employee } \\
\text { behaviour } \\
\text { flexibility. } \\
\text { HR practice } \\
\text { flexibility. }\end{array}$ & $\begin{array}{l}\text { Factor } \\
\text { Analysis. } \\
\text { Descriptive } \\
\text { Statistics. } \\
\text { Zero-Order } \\
\text { Correlations. } \\
\text { Questionnaire. }\end{array}$ & $\begin{array}{l}\text { Skill, behaviour, and } \\
\text { HR practice flexibility } \\
\text { are significantly } \\
\text { associated with an } \\
\text { index of firm financial } \\
\text { performance. } \\
\text { The authors find that } \\
\text { only skill flexibility } \\
\text { contributes to cost- } \\
\text { efficiency }\end{array}$ \\
\hline 3 & $\begin{array}{l}\text { Pronk, N. P., } \\
\text { Martinson, } \\
\text { Kessler, R. C., } \\
\text { Beck, A. L., Simon, } \\
\text { G. E., \& Wang, P. } \\
\text { (2004). The } \\
\text { Association } \\
\text { Between Work } \\
\text { Performance and } \\
\text { Physical Activity, } \\
\text { Cardiorespiratory } \\
\text { Fitness, and } \\
\text { Obesity }\end{array}$ & $\begin{array}{l}\text { Job } \\
\text { performance. }\end{array}$ & $\begin{array}{l}\text { Physical activity. } \\
\text { Cardiorespiratory } \\
\text { fitness. } \\
\text { Obesity. } \\
\text { Age. } \\
\text { Gender. } \\
\text { Education. } \\
\text { Height. } \\
\text { Weight. } \\
\text { Medical history. }\end{array}$ & $\begin{array}{l}\text { A probability } \\
\text { sample of } 2539 \\
\text { pre designated } \\
\text { respondents } \\
\text { was selected } \\
\text { equally from } 4 \\
\text { sampling } \\
\text { frames. }\end{array}$ & $\begin{array}{l}\text { Higher levels of } \\
\text { physical activity } \\
\text { related to reduced } \\
\text { decrements in quality } \\
\text { of work performed and } \\
\text { overall job } \\
\text { performance; higher } \\
\text { cardiorespiratory } \\
\text { fitness related to } \\
\text { reduced decrements in } \\
\text { quantity of work } \\
\text { performed, and a } \\
\text { reduction in extra } \\
\text { effort exerted to } \\
\text { perform the work; } \\
\text { obesity related to more } \\
\text { difficulty in getting } \\
\text { along with co-workers; } \\
\text { severe obesity related } \\
\text { to a higher number of } \\
\text { work loss days. }\end{array}$ \\
\hline 4 & $\begin{array}{l}\text { Holden, } \\
\text { Scuffham, P. A., } \\
\text { Hilton, M. } \\
\text { Vecchio, N. N., \& }\end{array}$ & $\begin{array}{l}\text { Work- } \\
\text { performance. } \\
\text { Absenteeism }\end{array}$ & $\begin{array}{l}\text { Age } \\
\text { Gender } \\
\text { Marital status } \\
\text { No. children }\end{array}$ & $\begin{array}{l}\text { Data collected } \\
\text { using the World } \\
\text { Health } \\
\text { Organization }\end{array}$ & $\begin{array}{l}\text { Hours expected to } \\
\text { work, annual wage, } \\
\text { and job insecurity play } \\
\text { a vital role in the }\end{array}$ \\
\hline
\end{tabular}




\begin{tabular}{|c|c|c|c|c|c|}
\hline & $\begin{array}{l}\text { Whiteford, H. A. } \\
(2010) . \quad \text { Work } \\
\text { Performance } \\
\text { Decrements Are } \\
\text { Associated With } \\
\text { Australian } \\
\text { Working } \\
\text { Conditions, } \\
\text { Particularly the } \\
\text { Demand to Work } \\
\text { Longer Hours. }\end{array}$ & & $\begin{array}{l}\text { Education level } \\
\text { Annual wage }\end{array}$ & $\begin{array}{l}\text { Health and } \\
\text { Productivity } \\
\text { Questionnaire } \\
\text { were analysed } \\
\text { with negative } \\
\text { binomial } \\
\text { logistic } \\
\text { regression and } \\
\text { multinomial } \\
\text { logistic } \\
\text { regressions. }\end{array}$ & $\begin{array}{l}\text { association between } \\
\text { health- and work- } \\
\text { related performance for } \\
\text { both work attendance } \\
\text { and self-reported work } \\
\text { performance }\end{array}$ \\
\hline 5 & $\begin{array}{l}\text { Arsenault, A., \& } \\
\text { Dolan, S. (1983). } \\
\text { The role of } \\
\text { personality, } \\
\text { occupation and } \\
\text { organization in } \\
\text { understanding the } \\
\text { relationship } \\
\text { between job stress, } \\
\text { performance and } \\
\text { absenteeism. }\end{array}$ & $\begin{array}{l}\text { Performance } \\
\text { Absenteeism }\end{array}$ & $\begin{array}{l}\text { JOB CONTEXT: } \\
\text { Restrictions on } \\
\text { behaviour } \\
\text { Skills } \\
\text { underutilization } \\
\text { Career ambiguity } \\
\text { Workload } \\
\text { instability } \\
\text { Pay inequity } \\
\text { Role ambiguity } \\
\text { Linguistic } \\
\text { pressure } \\
\text { JOB CONTENT: } \\
\text { Contact } \\
\text { patients with } \\
\text { Risky decisions } \\
\text { Physical risks } \\
\text { Job participation } \\
\text { Job responsibility }\end{array}$ & $\begin{array}{l}\text { Multiple } \\
\text { regression } \\
\text { Internal } \\
\text { reliability } \\
\text { coefficients } \\
\text { alpha } \\
\text { Regression } \\
\text { coefficients } \\
\text { Means }\end{array}$ & $\begin{array}{l}\text { Job content stress was } \\
\text { found to reduce } \\
\text { absenteeism but not to } \\
\text { influence perceived } \\
\text { performance, while job } \\
\text { context stress increases } \\
\text { absenteeism r and } \\
\text { reduces perceived } \\
\text { performance }\end{array}$ \\
\hline
\end{tabular}

The brief summary of some of the previous studies is given in the Table- 1 above and the methodologies used for conducting investigations of these studies including findings are highlighted in the table.

\section{Healthy Behaviour}

Employers can promote better health and life style at a workplace. Be healthy culture by developing workplace policies that support and promote healthy behaviours, a healthier physical work environment and other visible changes in the workplace are needs of the day that are also relating to employees' intention to stay. In this respect, the organisational culture has significant impact on the employees specially millennials' intention to stay (Islam et al., 2019). In addition to creating a healthier workplace, employers can promote better employee health by integrating health promotion initiatives that help their employees reduce health risks thus reduce incidence of chronic diseases. Unhealthy activity restrictions, which are the main drivers of poor health care costs organisations and lost worker productivity needs to be addressed (Terry, Seaverson, Grossmeier \& Anderson 2008). Employees who indicate healthy behaviours have a lower health risk, a lower prevalence of chronic disease, less absenteeism and higher work performance (Khan et al., 2019). According to the research of Towers and Perrin Health Care Cost Survey, the health dividend, capturing the value of employee health in 2009 has also shown that engaged employees have better and more productive physical health. Although the cause of this relationship is unclear, as physical health can positively affect engagement. 


\section{Conceptual Framework}

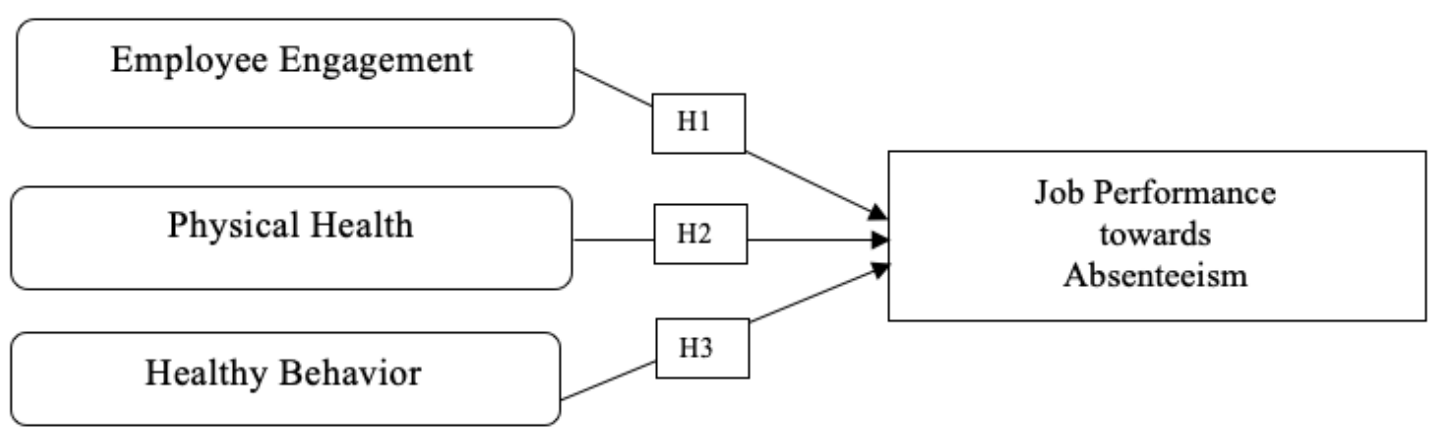

Fig.1 - Theoretical framework

H1: Increasing employee engagement is positively related to job performance towards reduce absenteeism.

H2: Employees' healthy behaviour is positively related to job performance towards absenteeism.

H3: Physical health is positively related to job performance towards reducing absenteeism.

\section{Data Collection Method}

\section{Methodology}

As mentioned in previous paragraph, a questionnaire is designed with twenty-six questions which comprises of the survey that addresses all variables which are discussed in the literature review such as employee engagement, healthy behaviour and physical health. With reference to the above mentioned variables their impact on job performance and absenteeism is examined in this study. Along with few questions related to the variables there were other questions as well. These questions are not mentioned in the literature review since these are demographic and income related aspects of respondents. However these are equally important which are about age, gender, marital status, education level, and income. For dependent variables questions were categorized on a five-level scale, were ranging from strongly agree to strongly disagree. Score one which is strongly disagree was considered as the least important where point five is the highest score which means strongly agree to the given question. For independent variables questions were categorized on a five-level scale, were either 'Yes' or straight 'No' and 'don't know'. However, for all questions, correlation is significant at the 0.05 level.

\section{Sampling}

In order to conduct survey on the "effect of employee engagement, healthy behaviour and physical health on job performance and absenteeism" in Saudi Arabia a quantitative approach as explained previously, was adopted. Questionnaire has been administered for collecting the data and involving employees in both public and private sectors (Hosen, Islam, Arshad, Khan, \& Alam, 2018). In addition, questionnaire covered the Saudi employees including men and women. Questionnaire was distributed among more than 150 Saudi employees to get their responses as employees' feedback. In this research the factor analysis is used to measure the effects and to find out the relationships between the variables; employee engagement, health behaviour and physical health (Khan, et al., 2019) It helps use a large number of variables that cannot easily be measured to understand them as these are the key factors of the study plan. Several variables with similar response patterns are displayed because they refer to the underlying variable. Also, in this study, regression analysis is also 
used to help on examining the influence of one or more independent variables on the dependent variable. The relationship between each independent variables and the dependent variable is represented by regression equation.

\section{Results and Discussion}

This section explores descriptive analysis and correlation analysis. The descriptive analysis section figures out the mean, median, mode, standard deviation and variance. In the correlation analysis again this chapter describes the relationship between all variables.

Table 2: Descriptive Analysis ( $n=185)$

\begin{tabular}{|c|c|c|c|}
\hline Measure & Items & Frequency & Percentage \\
\hline \multirow[t]{2}{*}{ Gender } & Male & 125 & 67.57 \\
\hline & Female & 60 & 32.43 \\
\hline \multirow[t]{4}{*}{ Age } & $18-29$ & 102 & 55.14 \\
\hline & $30-39$ & 53 & 28.65 \\
\hline & $40-49$ & 21 & 11.35 \\
\hline & Above 50 & 9 & 4.86 \\
\hline \multirow{4}{*}{$\begin{array}{l}\text { Educational } \\
\text { Qualification }\end{array}$} & High school & 91 & 49.19 \\
\hline & Bachelor's & 77 & 41.62 \\
\hline & Master & 12 & 6.49 \\
\hline & Doctorate & 5 & 2.7 \\
\hline \multirow[t]{2}{*}{ Marital status } & Single & 113 & 61.08 \\
\hline & Married & 72 & 38.92 \\
\hline \multirow{5}{*}{$\begin{array}{l}\text { Income/ Monthly } \\
\text { allowance }\end{array}$} & 7500SR-11999SR & 86 & 46.49 \\
\hline & 12000SR- 19999SR & 81 & 43.78 \\
\hline & 20000SR- 29999SR & 15 & 8.11 \\
\hline & 30000SR- 39999SR & 2 & 1.08 \\
\hline & Above 40000SR & 1 & 0.54 \\
\hline \multirow[t]{5}{*}{ Your experience } & $1-4$ years & 88 & 47.58 \\
\hline & 5-9 years & 63 & 34.05 \\
\hline & $10-15$ years & 18 & 9.73 \\
\hline & 16-24 years & 9 & 4.86 \\
\hline & Above 25 years & 7 & 3.78 \\
\hline
\end{tabular}

\section{Exploratory Factor Analysis (EFA)}

One of the main reasons to do reliability test is to check the consistency of the data. That refers to the degree to which the items that make up the scale are consistent with each other which means all the measuring express the same underlying construct. The reliability of 17 items in the questionnaire is investigated with Cronbach's Alpha. Ideally, the Cronbach's Alpha coefficient of a scale should be 0.7 and above (Pallant, 2007; Islam, Hunt, Jantan, Hashim \& Chong, 2019). Table 5 reveals Cronbach's Alpha for each variable, shows that, Alpha value 0.7 and above. KMO measures the proportion of variance in the variables that might be caused by an underlying factor. KMO test whether the partial correlations among variable are small. The basic guidelines for KMO indicate less than 0.5 which is considered poor whereas more than 0.8 is considered excellent. Table 2 shows good KMO value for this study which is 0.853 . Moreover, Bartlett's test whether the correlation matrix is an identity matrix (the diagonal values are 1 , and the off-diagonal values are 0 ). This 
condition just means that the variables are completely independent of each other and thus, the factor model is inappropriate. Identify matrix can be ruled out if the p-value of the test is less than 0.005 . Bartlett's test shows 0.000 which indicates that there is no high correlation or coefficient among the items and also suggests conducting EFA.

It is the percentage of the total variance among the variables that can be explained by the single factor. If the variables are independent of each other, then the total variance would be equal to the number of variables in the analysis. Table 3 shows four factors were extracted. First factor explains more variance $(36.272 \%)$ in the observed variables compared to the subsequent factors. Second factor provided $15.457 \%$ of the total variance. Third factor got a $9.757 \%$ of the total variance followed by fourth factor $(7.725 \%)$. There are seventeen factors in the construct, and four factors have been extracted. SPSS extracts all the factors with Eigen values greater than 1 .

According to table 4, Rotated component matrix shows the meaningful factor rotation. When more than one factor is extracted, the factor loadings would need to be rotated so that the factor structure can be explained meaningfully. This study used the varimax because it is an orthogonal rotation method that minimizes the number of variables that have high loadings on each factor. This method simplifies the interpretation of the factors.

Table 3: KMO and Bartlett's Test

\begin{tabular}{|l|l|l|}
\hline \multicolumn{3}{|c|}{ KMO and Bartlett's Test } \\
\hline Kaiser-Meyer-Olkin Measure of Sampling Adequacy. & 0.853 \\
\hline Bartlett's Test of Sphericity & Approx. Chi-Square & 1691.75 \\
\cline { 2 - 3 } & df & 136 \\
\cline { 2 - 3 } & Sig. & 0 \\
\hline
\end{tabular}

Table 4: Rotated component Matrix

\begin{tabular}{|c|c|c|c|c|}
\hline \multicolumn{5}{|c|}{ Rotated Component Matrix } \\
\hline Items & 1 & 2 & 3 & 4 \\
\hline JPA4 & 0.794 & & & \\
\hline JPA5 & 0.794 & & & \\
\hline JPA6 & 0.794 & & & \\
\hline JPA7 & 0.789 & & & \\
\hline JPA8 & 0.784 & & & \\
\hline JPA3 & 0.748 & & & \\
\hline JPA1 & 0.700 & & & \\
\hline JPA2 & 0.669 & & & \\
\hline EE1 & & 0.868 & & \\
\hline EE2 & & 0.849 & & \\
\hline EE3 & & 0.839 & & \\
\hline EE4 & & 0.720 & & \\
\hline HB2 & & & 0.844 & \\
\hline HB1 & & & 0.820 & \\
\hline HB3 & & & 0.799 & \\
\hline PH1 & & & & 0.864 \\
\hline PH2 & & & & 0.855 \\
\hline Initial Eigenvalues & 6.166 & 2.628 & 1.659 & 1.313 \\
\hline Oariance & 36.272 & 15.457 & 9.757 & 7.725 \\
\hline
\end{tabular}




\begin{tabular}{|c|c|}
\cline { 2 - 2 } Cumulative \% & 36.272 \\
\hline
\end{tabular}

Table 5: Reliability Test

\begin{tabular}{|l|l|l|}
\hline Component & Cronbach's Alpha & N of items \\
\hline Employee Engagement & 0.856 & 4 \\
\hline Physical Health & 0.771 & 2 \\
\hline Healthy Behaviour & 0.83 & 3 \\
\hline Job Performance and Absenteeism & 0.908 & 8 \\
\hline
\end{tabular}

\section{Regression Analysis}

The purpose of implementing the regression equation is to look at the variables that hold the best and give predictions for the dependent variable. All variables are including three independent against the dependent variable which is job performance and absenteeism. Table below shows the $(R$ correlation of three independent variables which are employee engagement, physical health and healthy behaviour influence the dependent variable which job performance which is $\mathrm{R}=0.660$. After inter-correlation $\mathrm{R}$ square is generated the square of $R^{2}=0.212$. The adjusted $R$ square is 0.199 which shows $19.9 \%$ of the variance on Job performance and absenteeism.

Table 6: Model Summary

\begin{tabular}{|l|l|l|l|l|}
\hline \multicolumn{5}{|l|}{ Model Summary } \\
\hline Model & $\mathrm{R}$ & R Square & $\begin{array}{l}\text { Adjusted R } \\
\text { Square }\end{array}$ & $\begin{array}{l}\text { Std. Error of } \\
\text { the Estimate }\end{array}$ \\
\hline 1 & $.660^{-}$ & .212 & .199 & .55452 \\
\hline a. Predictors: (Constant), mean_HB, mean_EE, mean_PH \\
\hline
\end{tabular}

ANOVA is another statistical technique to study the difference between two or more populations. A statistic $\mathrm{F}$ test is applied to test equality of the variance of two populations. Table shows that, the F calculated value of 16.190 is significant at the 0.000 level which stated the liner relationship between dependent and independent variables. This means that 16.190 percent of the variance (R-square) in job performance towards absenteeism is significantly represented by three independent variables. Therefore, there is an indication that the employee engagement, physical health and healthy behaviour value has substantial impact on enhancing the job performance and reduce absenteeism.

Table 7: ANOVA

\begin{tabular}{|c|c|c|c|c|c|c|}
\hline \multicolumn{7}{|c|}{ ANOVA $^{a}$} \\
\hline \multicolumn{2}{|c|}{ Model } & Sum of & df & Mean & $\mathrm{F}$ & Sig. \\
\hline \multirow[t]{3}{*}{1} & $\begin{array}{l}\text { Regressio } \\
\mathrm{n}\end{array}$ & 14.935 & 3 & 4.978 & 16.190 & .000 \\
\hline & Residual & 55.656 & 181 & .307 & & \\
\hline & Total & 70.591 & 184 & & & \\
\hline
\end{tabular}


Table below shows the regression of coefficient test which is applied to examine the coefficient between independent variables and dependent variable. The three independent variables resulted $19.9 \%$ of the variance on the dependent variable which is job performance and absenteeism.

$$
\begin{gathered}
y=a+b_{1} x_{1}+b_{2} x_{2}+b_{3} x_{3} \\
(\mathrm{JPA})=1.975+0.91 \mathrm{EE}+0.133 \mathrm{PH}+0.272 \mathrm{HB}
\end{gathered}
$$

This means that for every unit increase in employee engagement, job performance and absenteeism is expected to increase by 0.91 units, provided the order variables remain unchanged. Similarly, for every unit increase in psychical health, job performance and absenteeism is expected to increase by 0.133 units, provided that other variables remain unchanged. For every unit increase in healthy behavior, job performance and absenteeism is expected to increase by 0.272 units, provided the other variables remain unchanged. The $p$ value of employee engagement is 0.172 which is more than 0.05 shows the EE is not significant predictors for the JPA. The $p$ value of the other two variables irrespectively 0.020 and 0.000 which are less than 0.05 . As a result, it shows that, physical health and healthy behavior are the most significant predictors for the JPA.

\begin{tabular}{|c|c|c|c|c|c|c|}
\hline \multicolumn{7}{|c|}{ Coefficients $^{a}$} \\
\hline \multirow{2}{*}{\multicolumn{2}{|c|}{ Model }} & \multicolumn{2}{|c|}{$\begin{array}{c}\text { Unstandardized } \\
\text { Coefficients }\end{array}$} & \multirow{2}{*}{$\begin{array}{c}\text { Standardize } \\
\mathrm{d} \\
\text { Coefficients }\end{array}$} & \multirow[t]{2}{*}{$\mathrm{t}$} & \multirow[t]{2}{*}{ Sig. } \\
\hline & & B & Std. Error & & & \\
\hline \multirow[t]{4}{*}{1} & (Constant) & 1.975 & .324 & & 6.101 & .000 \\
\hline & Mean_EE & .091 & .066 & .098 & 1.370 & .172 (Not supported) \\
\hline & mean_PH & .133 & .057 & .168 & 2.352 & .020 (Supported) \\
\hline & mean_HB & .272 & .056 & .339 & 4.867 & .000 (Supported) \\
\hline
\end{tabular}

Table 8: Determinant Coefficient of JPA

\section{Hypothesis Testing}

From the Table 8 of regression analysis of coefficient it shows that a significant negative effect of the employee engagement and the job performance and absenteeism from the regression analysis. As the standardized coefficient value is $\beta=0.098$ and the $p$ - value of $0.172<0.05$. This means the Hypothesis $\mathrm{H} 1$ : employee engagement is positively related to job performance and absenteeism is not accepted. Thus should be eliminated from the list because the employee engagement is not a good predictor for this statement. However, this is inconsistent with the results presented by the study of Krueger \& Killham, (2005). This could be due to the changes culture, working environment and time that have also impact on the job performance and absenteeism of the employees in the organisations.

Regression analysis of coefficient also shows that the coefficient between physical health and job performance and absenteeism, a significant positive effect of the physical health and job performance and absenteeism from the regression analysis. As the standardized coefficient value is $\beta=0.168$ and the $p$ - value of $0.020<0.05$. This means the Hypothesis $\mathrm{H} 2$ is a good predictor for this statement. This result is corroborated with the 
study conducted by the Proper and van Mechelen (2008). Hence, it can be strongly argued that the psychical health is very much important for the development of the job performance and reduction of the absenteeism.

Furthermore, results also show that the coefficient between healthy behavior and job performance and absenteeism, a significant positive effect found from the regression analysis. As the standardized coefficient value is $\beta=0.339$ and the $p-$ value of $0.000<0.05$. This means the Hypothesis H3: is a good predictor for this statement. This result is also in light with the study conducted by Terry et al., (2008).

\section{Concluding Remarks}

Overall this study examined effect of the employee engagement, physical fitness and healthy lifestyle on job performance towards absenteeism and found some interesting outcome. Thus, this study opens up new grounds for further research. Future studies can address issues separately and should focus on distinguishing between each independent variable and place attention on the complete research on each ones' impacts separately on dependent variable separately. This may give more accurate results in the process of a questionnaire-based survey and data analysis, if it is done on wider area since it is carried out in one region such as this research which is based in Qassim region of Saudi Arabia. First, it is the culture of the local society which affected the results of the study. This study found out after the results and many discussions with different employees and colleagues that they have lacks of the effects of healthy behaviour on job performance and absenteeism. Researcher should write an introduction or definition of the independent and dependent variables and should have changed the method of survey from quantitative to qualitative and use of the language in the questionnaire to make it clearer for participants. Secondly, in the questionnaire researcher should have different set of questions and separate surveys for managers and employees. Usually managers have more concern about job performance and absenteeism rate than the employees. Therefore, in future for similar studies, if any, author should design two different surveys, one for managers and other for employees presumably was a limitation of this study. Finally, it seems the question numbers were not enough for each variable in the survey. These errors affected the final results. This should improve and be further developed to get better results in future, if another survey is conducted.

\section{References}

Altarawneh, I. I. (2016). Strategic Human Resources Management and its Impact on Performance: The Case from Saudi Arabia. International Journal of Business Management and Economic Research, 7(1), 486-503

Arsenault, A., \& Dolan, S. (1983). The role of personality, occupation and organization in understanding the relationship between job stress, performance and absenteeism. Journal of Occupational Psychology, 56(3), 227-240.

Bandura, A. (1997). Exercise of personal and collective efficacy in changing societies. Selfefficacy in Changing Societies, 1-45.

Bhattacharya, M., Gibson, D. E., \& Doty, D. H. (2005). The Effects of Flexibility in Employee Skills, Employee Behaviors, and Human Resource Practices on Firm Performance. Journal of Management, 31(4), 622-640.

Bacharach, S. B., Bamberger, P., \& Biron, M. (2010). Alcohol consumption and workplace absenteeism: The moderating effect of social support. Journal of Applied Psychology, 95, 334 -348. doi:10.1037/ a0018018

Bandura, A. (1997) Self-Efficacy: The Exercise of Control. New York: Freeman. 
Cascio, W. F. (2003). Changes in Workers, Work, and Organizations. Changes in Workers, Work, and Organizations. Retrieved April 15, 2003, from https://doi.org/10.1002/0471264385.wei1216.

Johns, G. (2003). How methodological diversity has improved our understanding of absenteeism from work. Human Resource Management Review, 13, 157-184.

Harrison, D. A., \& Price, K. H. (2003). Context of consistency in absenteeism: Studying social and dispositional influences across multiple settings. Human Resource Management Review, 13, 203-225.

Holden, L., Scuffham, P. A., Hilton, M. F., Vecchio, N. N., \& Whiteford, H. A. (2010). Work Performance Decrements Are Associated With Australian Working Conditions, Particularly the Demand to Work Longer Hours. Journal of Occupational and Environmental Medicine, 52(3), 281-290.

Hosen, S., Islam, M. A., Arshad, M. M., Khan, A. M., \& Alam, M. K. (2018). Talent management: An escalating strategic focus in Bangladeshi banking industry. International Journal of Academic Research in Business and Social Sciences, 8(1), 156-166.

Islam, M. A., Jantan, A. H., Hashim, H., \& Chong, C. W. (2020) Organisational culture and the millennials intention to stay: the mediating role of leadership management practices. International Journal of Business Excellence, 22(4), 1-21.

Islam, M. A., Hunt, A., Jantan, A. H., Hashim, H., \& Chong, C. W. (2019). Exploring challenges and solutions in applying green human resource management practices for the sustainable workplace in the ready-made garment industry in Bangladesh. Business Strategy \& Development. 3(1), 1-12

Kanfer, R. and Ackerman, P. L. (2005) 'Work competence: A Person-Oriented Perspective', in A. J. Elliot and C. S. Dweck (eds), Handbook of Competence and Motivation. Guilford Publications, pp. 336-353.

Khan, A. M., Jantan, A. H. B., Salleh, L. B. M., Dato'Mansor, Z., Islam, M. A., \& Hosen, S. (2019). The Impact of Transformational Leadership Effects on Innovative Work Behavior by the Moderating Role of Psychological Empowerment. Journal of Reviews on Global Economics, 8(1), 925-938.

Krueger J, Killham E. Gallup, Inc. (2005), “At Work, Feeling Good Matters”, available at: https://news.gallup.com/businessjournal/20311/work-feeling-good-matters.aspx

Merrill, R. M., Aldana, S. G., Pope, J. E., Anderson, D. R., Coberley, C. R., Grossmeier, J. J., \& Whitmer, R. W. (2013). Self-Rated Job Performance and Absenteeism According to Employee Engagement, Health Behaviors, and Physical Health. Journal of Occupational and Environmental Medicine, 55(1), 10-18.

Physical Activity Guidelines Advisory Committee. Physical Activity Guidelines Advisory Committee Report, 2008. Washington, DC: U.S. Department of Health and Human Services. 2008.

Pronk, N. P., Martinson, B., Kessler, R. C., Beck, A. L., Simon, G. E., \& Wang, P. (2004). The Association Between Work Performance and Physical Activity, Cardiorespiratory Fitness, and Obesity. Journal of Occupational and Environmental Medicine, 46(1), 19-25.

Proper, K., van Mechelen, W., (2008), "Effectiveness and economic impact of worksite interventions to promote physical activity and healthy diet. World Health Organization," available at: http://www.who.int/dietphysicalactivity/Proper_K.pdf. (accessed 11/7/08). 
Schneider, B. (2006). First, Break All the Rules: What the World's Greatest Managers Do Differently First, Break All the Rules: What the World's Greatest Managers Do Differently By Buckingham Marcus and Coffman Curt. Published by Simon and Schuster, 1999. Academy of Management Perspectives, 20(1), 125-129.

Terry, P. E., Seaverson, E. L., Grossmeier, J., \& Anderson, D. R. (2008). Association Between Nine Quality Components and Superior Worksite Health Management Program Results. Journal of Occupational and Environmental Medicine, 50(6), 633641.

Tiwari, M., Sharma, D., Dwivedi, S., Singh, M., Tripathi, R. D., \& Trivedi, P. K. (2013). Expression inArabidopsisand cellular localization reveal involvement of rice NRAMP, OsNRAMP1, in arsenic transport and tolerance. Plant, Cell \& Environment, 37(1), 140-152.

Rhodes, S., \& Steers, R. M. (1990). Managing employee absenteeism. Reading, MA: Addison Wesley. 